\title{
Comparative study of the nutritional potential of a wild fruit (Saba senegalensis) from Côte d'Ivoire with pineapple, papaya and banana
}

\author{
Yapi Elisée KOUAKOUA*, Aïssatou COULIBALY, Olivier kouadio KOUADIO, \\ Eliane Hadiowe GNAGNE and N'Guessan Georges AMANI
}

Biochemistry and Tropical Products Technology Laboratory, University of Nangui Abrogoua, Abidjan, 02 BP 801 Abidjan 02, Côte d'Ivoire.

*Corresponding author; E-mail: kouakouaelisee@gmail.com

Received: 11-06-2021

Accepted: 15-10-2021

Published: 30-10-2021

\begin{abstract}
Saba senegalensis fruit is traditionally collected and sold on the Ivorian markets, although it is considered as an underutilized species in favour of commercial fruits. The present study aimed at providing data on the nutritional value of Saba senegalensis fruit in comparison with widely valued fruits. Saba senegalensis pulp as well as dessert banana, papaya and pineapple pulp were used as study material. After an evaluation of the biochemical parameters, a principal component analysis (PCA) was used to highlight the nutritional potential of the different fruits. The results showed that the physicochemical parameters varied from one fruit to another. The Saba senegalensis fruit stood out from the other three fruits by its high antioxidant activity (IC50 = 39.80 \pm 0.45 $\mathrm{mg} / \mathrm{ml})$, its high concentration of polyphenols $(600.94 \pm 5.27 \mathrm{mg} \mathrm{EqA} . \mathrm{G} / 100 \mathrm{~g})$, flavonoids $(245.09 \pm 19.10$ mg EqA.G / $100 \mathrm{~g})$, vitamin A (1.96 $\pm 0.03 \mathrm{mg} / 100 \mathrm{~g}), \mathrm{Ca}(29.19 \pm 0.17)$ and Fe $(2.51 \pm 0.06 \mathrm{mg} / 100 \mathrm{~g})$. These nutritional constituents are far superior in Saba senegalensis pulp to those of banana, papaya and pineapple. Thus, its nutritional potential could be a major asset for its consumption and valorisation (C) 2021 International Formulae Group. All rights reserved.
\end{abstract}

Keywords: Saba senegalensis, wild fruit, principal component analysis (PCA), nutritional potential, Côte d'Ivoire.

\section{INTRODUCTION}

Saba senegalensis is an indigenous vine belonging to the Apocynaceae family. It is found in the wild in northern part of Côte d'Ivoire and also in other countries such as Burkina Faso, Gambia, Guinea, Mali, Niger, Guinea-Bissau, Senegal, Tanzania and Ghana (Arbonnier, 2002). As an indigenous fruits tree, Saba senegalensis fruit is called by different language dialects. This fruit is called Saba in
French, zaban in Malinké language, wèda in Mooré, Madd in Wolof and côcôta in the urban language of Côte d'Ivoire. The interest of Saba senegalensis in feeding and treating hundreds of diseases in rural Populations is widely recognized (Gning et al., 2013). Indeed, it is used for the treatment of certain diseases such as dysentery, diarrhoea and cough (Koné et al., 2012; Gning et al., 2014; Ballo et al., 2020; Angaman et al., 2001). The fruit consists of a 
globular shell enclosing very soft and juicy yellow pulp seeds (Kini et al., 2008).

In Senegal and Mali, Saba senegalensis fruit is widely valued and consumed. It is processed into juice and sold on these different markets (Edmée and Sidia, 2020; Kouyaté et al., 2021). In contrast to these countries, little processing is carried out on the fruit in Côte d'Ivoire. It is found in its raw state on the national market between May and September (Kini et al., 2008). The lack of exploitation of this fruit in the country could not only lead to economic losses for the rural world but also dishearten those who consider its harvest as a major activity such as agriculture, livestock and fishing (Edmée and Sidia, 2020). The lack of nutritional knowledge of this fruit and the competition on the market with export fruits that have already been established in the population's eating habits could explain its non-valuation.

Several studies have characterized this fruit, but its overall nutritional positioning in relation to mainstream fruits has never been determined. The daily consumption in sufficient amounts the fruits is known to prevent diseases such as cardiovascular disease and some cancers (WHO/FAO, 2014). Thus, the nutritional potential of the Saba senegalensis fruit is essential to promote the importance of its health benefits and generate particular interest in its valuation.

The objective of this work was to highlight the nutritional contribution of the Saba senegalensis fruit in comparison with widely valued fruits.

\section{MATERIALS AND METHODS Study material}

The plant material consisted of Saba senegalensis fruits, dessert banana (Musa triploid AAA, Cavendish, cv Grande Naine), papaya (Carica papaya L.) and pineapple (Ananas comosus). The fruits of Saba senegalensis were collected at an advanced stage of ripeness (orange) in the region of Korhogo and those of the MD2 pineapple variety at the ripe stage (green) came from Bonoua. The sweet banana of the cultivar
Grande naine and the ripe (green) solo papaya were harvested in the Azaguié region. The collected fruits were brought to the Biochemistry and Tropical Products Technology Laboratory of the Université Nangui Abrogoua in Abidjan, and stored in crates at room temperature $\left(27 \pm 1{ }^{\circ} \mathrm{C}\right)$. The commercial ripeness of dessert banana, papaya and pineapple was observed subjectively by following the colouration of the pericarp. These three fruits reached the yellow-green, yellowish-green and orange-yellow stage respectively, taking into account the ripeness stages described by the CEE-ONU standard (2013).

\section{Methods}

\section{Preparation of fruit pulps}

The selected Saba senegalensis fruits were washed to remove dirt and most of the surface microorganisms. The globular shell containing the seeds coated with yellow pulp was broken with a stainless-steel knife. The pulp was separated from the seeds by kneading and straining. The peeled dessert banana, papaya and pineapple pulps were mixed using a ZBK220077-88LW74d blender. The different pulp extracts obtained were used for the different laboratory analyses.

\section{Biochemical analysis \\ Proximal composition}

The proximal composition was determined according to the method (AOAC, 1990). The moisture content was determined by drying in an oven at $105{ }^{\circ} \mathrm{C}$ to a constant weight. Ash was determined by weighing the residue obtained by incineration at $550{ }^{\circ} \mathrm{C}$ for 8-12 hours. The total crude protein content was determined by the Kjeldahl method. The total lipid content of the samples was determined gravimetrically after extraction with Soxhlet. Fibre was determined after acid boiling under reflux cooling.

\section{Mineral composition}

The contents of $\mathrm{Ca}, \mathrm{Mg}, \mathrm{K}, \mathrm{Na}, \mathrm{Fe}, \mathrm{Mn}$, $\mathrm{Cu}$ and $\mathrm{Zn}$ were determined by atomic absorption spectroscopy after wet mineralisation (AOAC, 1990). 


\section{Soluble sugars}

To five (5) $\mathrm{g}$ of pulp, $50 \mathrm{ml}$ of distilled water was added. After five (5) min homogenisation with a magnetic stirrer and 20 min centrifugation at $4000 \mathrm{G}$ (GMA laboratory centrifuge, D-37520, Germany), $50 \mathrm{ml}$ of the supernatant was pipetted into a $200 \mathrm{ml}$ volumetric flask and made up to the mark. Reducing sugars were determined by the method of Bernfeld (1955) using DNS (dinitrosalicylic acid). The optical density (OD) reading was taken at 540. As for the determination of total sugars, the measurement was performed according to the method described by Dubois et al. In the presence of phenol and sulphuric acid, the solution took on a yellow-orange colour, the intensity of which is proportional to the carbohydrate concentration. The intensity of this coloration was measured at $490 \mathrm{~nm}$. A UV spectrophotometer (AQUALYTIC AL800, Germany) was used throughout the above two analyses. The amounts of total reducing and soluble sugars were expressed in grams per 100 $\mathrm{g}$ fresh weight. Glucose was used as a reference at $200 \mu \mathrm{g} / \mathrm{ml}$.

\section{$\beta$-carotene content}

The determination of $\beta$-carotene was carried out by adaptation of the method of Aké et al. (2001). A quantity of $10 \mathrm{~g}$ of sample was weighed and ground in $40 \mathrm{ml}$ of ethanol. The ground material was poured into a separating funnel to which $50 \mathrm{ml}$ of hexane was added. The supernatant was collected and $50 \mathrm{ml}$ of hexane was added again. The supernatant was removed and evaporated in the oven at $45{ }^{\circ} \mathrm{C}$ for 24 hours. A quantity of $4 \mathrm{ml}$ of the sample was taken and the optical density (OD) reading was taken with a spectrophotometer at $450 \mathrm{~nm}$.

\section{Determination of total polyphenols}

The determination of total polyphenols (in mg G.E / $\mathrm{g}$ fresh matter) was carried out by adapting the method of Wood et al. To five (5) $\mathrm{g}$ of pulp, $50 \mathrm{ml}$ of distilled water was added. After $5 \mathrm{~min}$ of homogenisation using a magnetic stirrer, the solution was filtered through cotton wool. Using a pipette, 1 $\mathrm{ml}$ of the filtrate is withdrawn and inverted into a beaker. To this volume, $1 \mathrm{ml}$ of the Folinciocalteu reagent is added and homogenised by manual shaking. After 3 min, a volume of $1 \mathrm{ml}$ of an aqueous solution of sodium carbonate $(20 \%, w / v)$ was added and the volume was adjusted to $10 \mathrm{ml}$ with distilled water. The tube was then put in the dark for $30 \mathrm{~min}$. The absorbance was read with a UV spectrophotometer (AQUALYTIC AL800, Germany) at $760 \mathrm{~nm}$ against the blank. Finally, a calibration curve was performed using a range of gallic acid concentrations from 0 to 1 $\mathrm{mg} / \mathrm{ml}$. The results were expressed as $\mathrm{mg}$ gallic acid equivalent (GAE)/100 $\mathrm{g}$ fresh matter (DM).

\section{Determination of total flavonoids}

The determination of total flavonoids was performed according to the method described by Marinova et al. To five (5) $g$ of pulp, $50 \mathrm{ml}$ of distilled water was added. After 5 min of homogenisation using a magnetic stirrer, the solution was filtered through cotton wool. To a volume of $0.5 \mathrm{ml}$ of the filtrate were successively added $0.5 \mathrm{~mL}$ distilled water, 0.5 $\mathrm{ml}$ aluminium chloride (10\% w/v), $0.5 \mathrm{ml}$ sodium acetate $(1 \mathrm{M})$ and $2 \mathrm{~mL}$ distilled water. The contents were then left to stand for $20 \mathrm{~min}$ in the dark and the absorbance was read with a UV spectrophotometer (AQUALYTIC AL800, Germany) at $415 \mathrm{~nm}$ against a blank. Finally, a calibration curve was performed using a range of quercetin concentrations from 0 to 0.1 $\mathrm{mg} / \mathrm{ml}$. The results were expressed as $\mathrm{mg}$ quercetin equivalent (QE)/100 $\mathrm{g}$ fresh material.

\section{Total antioxidant capacity}

The determination of antioxidant capacity was carried out by slightly modifying the method of Muanda (2010) using 2,2diphenyl-1-picrylhydrazyl (DPPH). Various amounts of the samples dissolved in methanol were added to $5 \mathrm{ml}$ of a $0.004 \%$ methanol solution of DPPH (2,2-diphenyl-1picrylhybrid). DPPH (2,2-diphenyl-1picrylhydrazyl, free radical). After 30 minutes of incubation at room temperature, the absorbance was read against a blank at room temperature. At room temperature, absorbance was read against a blank at $517 \mathrm{~nm}$ (20). Vitamin C was used as a positive control. The percentage of DPPH free radical inhibition (I\%) was calculated according to the equation below. The linear regression between the 
different inhibition percentages and concentrations then allows the median inhibitory concentration $\left(\mathrm{IC}_{50}\right)$ to be determined.

$$
\begin{gathered}
\mathrm{I} \%=(\text { Absorbance control }- \text { Absorbance } \\
\text { sample } / \text { Absorbance control }) \times 100
\end{gathered}
$$

\section{Statistical analysis}

The results of the analyses were submitted to an analysis of variance (ANOVA) at the 0.05 level of significance using XLSTAT software (Version 19.6). The Tukey test was used to determine significant differences between the samples. After the ANOVA, a principal component analysis (PCA) was performed for the discrimination of the different fruits.

\section{RESULTS}

\section{Proximal composition}

Table 1 presents the biochemical characteristics of Saba senegalensis, dessert banana, papaya and pineapple pulps. The results revealed the existence of significant difference $(\mathrm{P}<0.05)$ at the $5 \%$ threshold on all the parameters studied. All the fruits studied had high water content, but with a predominance in papaya $(88.10 \pm 0.87 \%)$ and pineapple $(87.13 \pm 0.71 \%)$. The fibre concentration was higher in papaya $(0.67 \pm$ $0.00 \mathrm{~g} / 100 \mathrm{~g}$ MF) compared to other fruits. The lowest concentrations were recorded in Saba senegalensis and banana pulp. For lipids, the highest content was observed in pineapple pulp $(0.88 \pm 0.01 \mathrm{~g} / 100 \mathrm{~g} \mathrm{MF})$, followed by Saba senegalensis, banana and papaya. For protein, sugars and ash content, banana had the highest concentrations. With a concentration of $1.96 \pm$ $0.03 \mathrm{mg} / 100 \mathrm{~g}$ MF, Saba senegalensis pulp was the richest in $\beta$-carotene.

\section{Minerals}

The mineral analysis of the 4 fruit samples has been represented in Table 2. The most prevalent minerals in all fruits were Potassium (K), Magnesium (Mg) and Calcium (Ca). The results showed that from one fruit to another the mineral concentration varied significantly $(\mathrm{P}<0.05)$ at the $5 \%$ threshold. Banana recorded the highest concentrations of
$\mathrm{K}(426.94 \pm 0.73 \mathrm{mg} / 100 \mathrm{~g} \mathrm{MF})$ and $\mathrm{Mg}(38.41$ $\pm 0.08 \mathrm{mg} / 100 \mathrm{~g} \mathrm{MF})$. Saba senegalensis pulp had a high concentration of $\mathrm{Ca}(29.19 \pm 0.17$ $\mathrm{mg} / 100 \mathrm{~g} \mathrm{MF}$ ), as well as a high concentration of $\mathrm{Mg}$ which is significantly the same as that of banana. Papaya and pineapple recorded the lowest concentrations of macroelements. With regard to trace elements, Saba senegalensis pulp is richer in $\mathrm{Fe}(2.51 \pm 0.06 \mathrm{mg} / 100 \mathrm{~g} \mathrm{MF})$. On the other hand, this fruit recorded no concentration of Manganese (Mn) and Copper $(\mathrm{Cu})$. Banana and pineapple recorded the highest concentrations of $\mathrm{Mn}$. For $\mathrm{Cu}$ the highest concentration was observed in banana pulp $(0.07 \pm 0.00 \mathrm{mg} / 100 \mathrm{~g} \mathrm{MF})$. The concentration of Zinc ( $\mathrm{Zn})$ is higher in pineapple and lower in banana.

\section{Antioxidant composition of pulps}

The antioxidant activity and total polyphenol and flavonoid components of the 4 fruit pulps are presented in Table 3. The antioxidant activity as well as the total polyphenol and flavonoid components vary ( $\mathrm{P}$ $<0.05$ ) at the $5 \%$ threshold from one fruit to another. Saba senegalensis pulp had the highest antioxidant activity $(39.80 \pm 0.45$ $\mathrm{mg} / \mathrm{ml})$ as well as the highest concentrations of total polyphenols $(600.94 \pm 5.27 \mathrm{mg}$ EqA.G $/ 100 \mathrm{~g})$ and flavonoids $(245.09 \pm 19.10 \mathrm{mg}$ Q.E/100 g). Pineapple had the lowest concentrations of total polyphenols and flavonoids. The lowest antioxidant activity was observed with banana pulp.

\section{Discrimination of different fruits}

The biochemical variability of the fruits wasdescribed using principal component analysis (PCA). The principal component analysis carried out with all the biochemical variables measured made it possible to distribute the fruits and position them according to their nutritional potential in the plane formed by the F1 and F2 axes as shown in Figure 1. The main axes noted F1 and F2 have a contribution of $87.13 \%$ to the total variability, i.e. an individual contribution of $47.75 \%$ for the $\mathrm{Fl}$ axis and $39.38 \%$ for the F2 axis. The variables protein, $\beta$-carotene, phenolic compound, flavonoid, total sugars, 
reducing sugars, $\mathrm{K}, \mathrm{Ca}, \mathrm{Fe}$ and $\mathrm{Cu}$ contribute to the formation of the FI axis. The F2 axis is formed by the variables moisture $(\mathrm{H})$, ash, $\mathrm{Na}$, $\mathrm{Zn}$ and $\mathrm{Mg}$. The representation of the fruits in the plane formed by the FI and F2 axes highlights the biochemical variability of the 4 fruits. Saba senegalensis pulp is characterised by a high concentration of polyphenols, flavonoids, $\beta$-carotene (vitamin $\mathrm{A}$ ), $\mathrm{Ca}, \mathrm{Fe}$ and acids. Banana stands out from other fruits by its high concentration of ash, protein, total sugars, reducing sugars, $\mathrm{K}, \mathrm{Mg}, \mathrm{Na}, \mathrm{Mn}$ and $\mathrm{Cu}$. Pineapple is distinguished by its high water and $\mathrm{Zn}$ content. Papaya is richer in fibre.

Table 1: Biochemical characteristics of different fruits.

\begin{tabular}{lcccc}
\hline \multirow{2}{*}{ Parameter } & \multicolumn{4}{c}{ Pulps } \\
\cline { 2 - 5 } & Saba & Banana & Papaya & Pineapple \\
\hline Moisture (g/100 g) & $85.27 \pm 0.37^{\mathrm{b}}$ & $79.67 \pm 0.57^{\mathrm{c}}$ & $88.10 \pm 0.87^{\mathrm{a}}$ & $87.13 \pm 0.71^{\mathrm{a}}$ \\
Fibre (g/100 g) & $0.18 \pm 0.02^{\mathrm{c}}$ & $0.29 \pm 0.16^{\mathrm{c}}$ & $0.67 \pm 0.00^{\mathrm{a}}$ & $0.53 \pm 0.11^{\mathrm{b}}$ \\
Ash (g/100 g) & $0.58 \pm 0.01^{\mathrm{b}}$ & $1.18 \pm 0.07^{\mathrm{a}}$ & $0.47 \pm 0.06^{\mathrm{b}}$ & $0.30 \pm 0.08^{\mathrm{b}}$ \\
Lipid (g/100 g) & $0.81 \pm 0.02^{\mathrm{b}}$ & $0.65 \pm 0.01^{\mathrm{c}}$ & $0.32 \pm 0.003^{\mathrm{d}}$ & $0.88 \pm 0.01^{\mathrm{a}}$ \\
Protein (g/100 g) & $0.32 \pm 0.01^{\mathrm{d}}$ & $1.35 \pm 0.01^{\mathrm{a}}$ & $0.68 \pm 0.01^{\mathrm{b}}$ & $0.55 \pm 0.01^{\mathrm{c}}$ \\
T-sugars (g/100 g) & $6.50 \pm 0.39^{\mathrm{d}}$ & $15.83 \pm 0.78^{\mathrm{a}}$ & $8.67 \pm 0.66^{\mathrm{c}}$ & $10.66 \pm 0.03^{\mathrm{b}}$ \\
r-sugars (g/100 g) & $2.64 \pm 0.23^{\mathrm{c}}$ & $5.38 \pm 0.20^{\mathrm{a}}$ & $4.10 \pm 0.13^{\mathrm{b}}$ & $4.10 \pm 0.13^{\mathrm{b}}$ \\
及-carotene (mg/100 g) & $1.96 \pm 0.03^{\mathrm{a}}$ & $0.93 \pm 0.34^{\mathrm{b}}$ & $0.64 \pm 0.54^{\mathrm{c}}$ & $0.53 \pm 0.15^{\mathrm{c}}$
\end{tabular}

Values in the same row with the same letter are not significantly different from each other according to Tukey's multiple comparison test at the 5\% level. Values are expressed as Mean \pm Standard Deviation $(n=3$ trials). T-sugars: total sugars, $\mathrm{r}$ sugars: reducing sugars.

Table 2: Mineral concentration $(\mathrm{mg} / 100 \mathrm{~g})$ of fruit pulps.

\begin{tabular}{lcccc}
\hline Minerals & \multicolumn{4}{c}{ Pulps } \\
\cline { 2 - 5 } & Saba & Banana & Papaya & Pineapple \\
\hline Potassium (K) & $148.31 \pm 0.62^{\mathrm{c}}$ & $426.94 \pm 0.73^{\mathrm{a}}$ & $210.81 \pm 0.54^{\mathrm{b}}$ & $121.04 \pm 0.12^{\mathrm{c}}$ \\
Calcium (Ca) & $29.19 \pm 0.17^{\mathrm{a}}$ & $5.62 \pm 0.13^{\mathrm{b}}$ & $8.23 \pm 0.24^{\mathrm{b}}$ & $3.96 \pm 0.07^{\mathrm{b}}$ \\
Sodium (Na) & $3.99 \pm 0.02^{\mathrm{b}}$ & $5.18 \pm 0.08^{\mathrm{a}}$ & $1.51 \pm 0.01^{\mathrm{c}}$ & $1.45 \pm 0.01^{\mathrm{c}}$ \\
Magnésium (Mg) & $37.58 \pm 0.63^{\mathrm{a}}$ & $38.41 \pm 0.08^{\mathrm{a}}$ & $6.69 \pm 0.02^{\mathrm{b}}$ & $3.65 \pm 0.01^{\mathrm{c}}$ \\
Iron (Fe) & $2.51 \pm 0.06^{\mathrm{a}}$ & $0.27 \pm 0.01^{\mathrm{b}}$ & $0.26 \pm 0.00^{\mathrm{b}}$ & $0.32 \pm 0.00^{\mathrm{b}}$ \\
Manganese (Mn) & nd & $0.31 \pm 0.01^{\mathrm{a}}$ & $0.01 \pm 0^{\mathrm{b}}$ & $0.28 \pm 0.00^{\mathrm{a}}$ \\
copper (Cu) & nd & $0.07 \pm 0.00^{\mathrm{a}}$ & $0.01 \pm 0.00^{\mathrm{b}}$ & nd \\
Zinc (Zn) & $0.08 \pm 0.01^{\mathrm{b}}$ & $0.03 \pm 0.00^{\mathrm{c}}$ & $0.09 \pm 0.00^{\mathrm{c}}$ & $0.11 \pm 0.00^{\mathrm{a}}$ \\
\hline
\end{tabular}

Values in the same row with the same letter are not significantly different from each other according to Tukey's multiple comparison test at the $5 \%$ level. Values are expressed as Mean \pm Standard Deviation ( $n=3$ trials). nd: not detected. 
Table 3: $\mathrm{IC}_{50}$ and Concentration of total polyphenols and flavonoids.

\begin{tabular}{lcccc}
\hline Parameters & \multicolumn{4}{c}{ Pulps } \\
\cline { 2 - 5 } & Saba & Banana & Papaya & Pineapple \\
\hline IC50 $(\mathbf{m g} / \mathbf{m l})$ & $39.80 \pm 0.45^{\mathrm{d}}$ & $349.99 \pm 52.52^{\mathrm{a}}$ & $77.02 \pm 8.05^{\mathrm{c}}$ & $109.65 \pm 4.66^{\mathrm{b}}$ \\
Total polyphenols & $600.94 \pm 5.27^{\mathrm{a}}$ & $149.66 \pm 0.53^{\mathrm{b}}$ & $142.83 \pm 1.35^{\mathrm{b}}$ & $145.26 \pm 0.85^{\mathrm{b}}$ \\
$(\mathbf{m g}$ EqA.G/100 g) & & & & \\
Flavonoid (mg & $245.09 \pm 19.10^{\mathrm{a}}$ & $81.55 \pm 12.57^{\mathrm{b}}$ & $20.13 \pm 3.82^{\mathrm{d}}$ & $41.57 \pm 5.59^{\mathrm{c}}$ \\
EqA.G/100 g) & & & & \\
\hline
\end{tabular}

Values in the same row with the same letter are not significantly different from each other according to Tukey's multiple comparison test at the 5\% level. Values are expressed as Mean \pm Standard Deviation $(n=3$ trials).

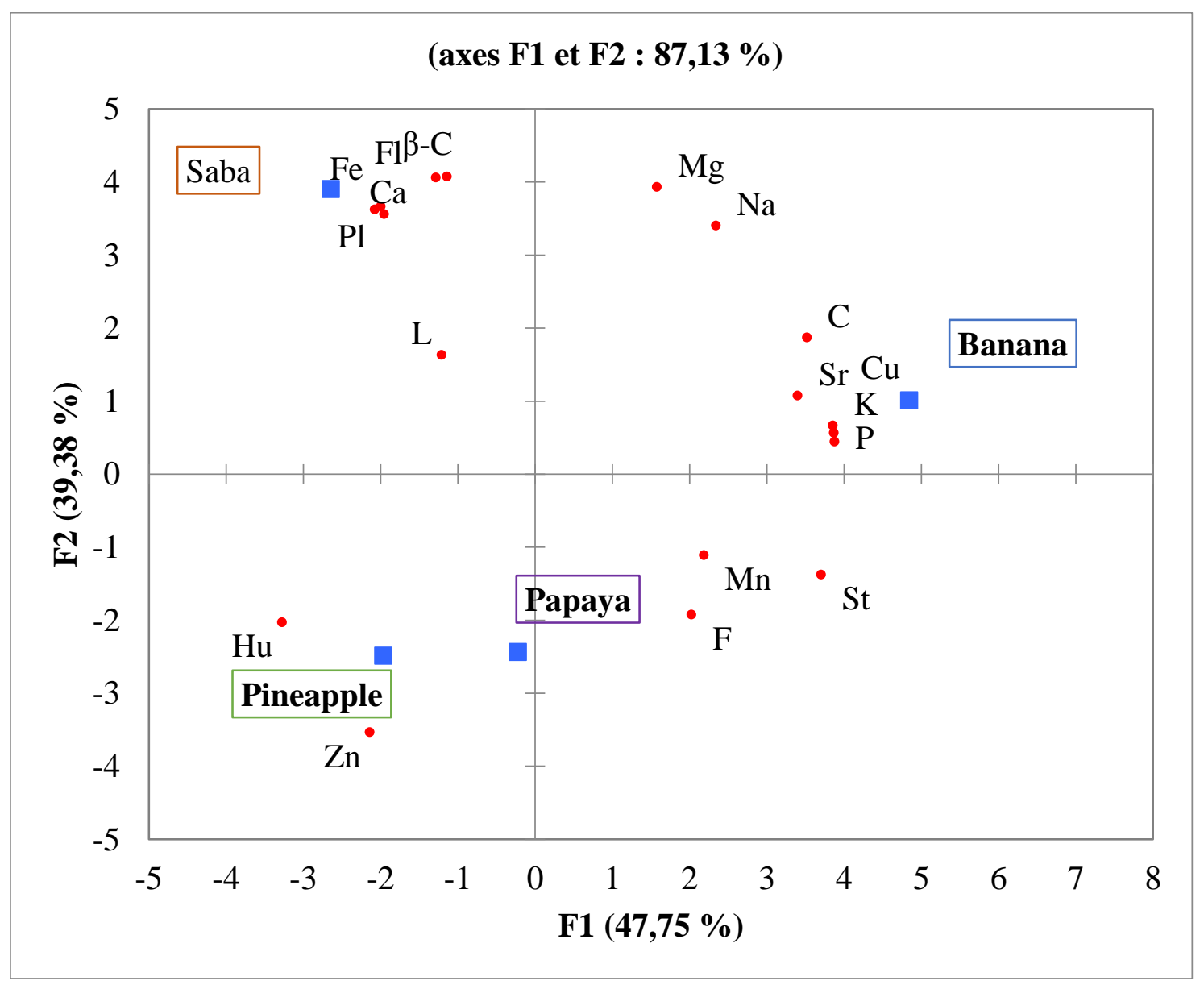

Figure 1: Two-dimensional representation of biochemical variables and fruits (individuals).

$\mathrm{P}=$ protein, $\mathrm{St}=$ total sugars, $\mathrm{Sr}=$ reducing sugar, $\mathrm{Pl}=$ polyphenol, $\mathrm{H}=$ moisture, $\mathrm{C}=$ ash,$\beta-\mathrm{C}=\beta$-carotene, $\mathrm{Fl}=$ flavonoid, $\mathrm{L}=$ lipid, $\mathrm{F}=$ fibre, $\mathrm{Ca}=$ calcium, $\mathrm{K}=$ potassium, $\mathrm{Na}=$ sodium, $\mathrm{Mg}=$ magnesium, $\mathrm{Mn}=$ manganese, $\mathrm{Fe}=$ iron, $\mathrm{Cu}=$ copper, $\mathrm{Zn}=$ zinc. 


\section{DISCUSSION}

The present study highlighted the nutritional differences between $S a b a$ senegalensis pulp and the other three (3) fruits (banana, papaya and pineapple).

According to the biochemical parameters and the distribution of variables carried out by PCA, Saba senegalensis pulp is distinguished from the other fruits by its composition in polyphenols, flavonoids, $\beta$ carotene (vitamin A), Ca and Fe. Also, the fruit has a very high antioxidant activity. This fruit alone contained 48,57 and $63 \% \beta$-carotene, polyphenols and flavonoids respectively compared to the other 3 fruits studied. The high concentration of these compounds has been highlighted by several authors (Kini et al., 2012; Sarr et al., 2018; Diabagaté et al., 2019). According to the studies by Diabagaté et al. (2019) and Sarr et al. (2018), the polyphenol concentration of Saba senegalensis pulp varied between 264.76 and $945.83 \mathrm{mg}$ EqA.G/100 g. Flavonoids and $\beta$-carotene were in the range of 53.44 and $1.55 \mathrm{mg}$ EqA.G/100 g (Kini et al., 2012; Diabagaté et al., 2019). The variation in flavonoid concentration observed in the study could be explained by the variety and maturity status of the fruit. Together, these compounds provide strong antioxidant activity to $S a b a$ senegalensis fruit. As the results of this study show, the $\mathrm{IC}_{50}$ of Saba senegalensis pulp is $39.80 \mathrm{mg} / \mathrm{ml}$ which is 2,3 and 9 times higher than that of papaya, pineapple and banana respectively. In the literature, no study has been conducted on the antioxidant activity of Saba pulp, but studies conducted on the leaves have revealed the high antioxidant activity of the plant (Sarr et al., 2015; Yougbaré-Ziébrou et al., 2015). Yougbaré-Ziébrou et al (2015) obtained an IC50 of $18, \mu \mathrm{g} / \mathrm{ml}$ from the freezedried aqueous extract of the Saba senegalensis leaf stem. At the mineral level, Saba senegalensis pulp is distinguished by its high $\mathrm{Ca}$ and $\mathrm{Fe}$ concentration. The Saba senegalensis fruit expresses $61 \%$ and $74 \%$ respectively of these two minerals that could be provided by all four fruits. With samples collected in the region of Korhogo, Diabagaté et al (2019) recorded concentrations of 36.61 and $1.04 \mathrm{mg} / 100 \mathrm{~g}$. In Burkina Faso,
Tiendrebeogo et al (2020) recorded concentrations of 130.2 and $2.54 \mathrm{mg} / 100 \mathrm{~g}$. This difference could be justified by differences in soil, climate and fruit maturity level. As the daily requirements of these minerals are 1200 and $8.1 \mathrm{mg} /$ day, the consumption of $100 \mathrm{~g}$ of this pulp could cover $2.4 \%$ and $30 \%$ of the requirements. All this nutritional richness could be very beneficial for the health of the consumer. Indeed, in addition to having a strong antioxidant activity, the fruit could contribute to improve the vision. The $\mathrm{Ca}$ and iron they contain play an important role in our bodies. Calcium is essential for muscle contraction, oocyte activation, bone and tooth formation, blood clotting, nerve impulses, transmission and regulation of heart rhythm (Piste et al., 2013). Iron is a component of haemoglobin and plays a fundamental role in gas exchange, particularly in oxygen transport in red blood cells (Abbaspour et al., 2014).

In addition to its potential, Saba senegalensis pulp in comparison to pineapple and papaya was less rich in fibre. The low fibre concentration obtained in the study could be justified by the pulp extraction method. In the literature, this concentration varied between 1.3 and $13.52 \mathrm{mg} / 100 \mathrm{~g}$ (Sarr et al., 2018). Saba senegalensis pulp would also differ from banana in its concentration of sugars, protein and K. Saba senegalensis pulp is half as rich in sugars as banana. This difference in concentration has allowed the Saba senegalensis fruit to be positioned as a lowsugar fruit. In the literature, Diabagaté et al (2019) reported a concentration of $6 \mathrm{~g} / 100 \mathrm{~g}$ for total sugars and $2 \mathrm{~g} / 100 \mathrm{~g}$ for reducing sugars in Saba senegalensis pulp. These results are very close to the one obtained in this study. Like sugars, proteins are 2 times less concentrated in Saba senegalensis pulp than in banana. The low concentration of protein in Saba senegalensis pulp has already been highlighted by Boamponsem et al (2013). In terms of minerals, apart from the absence of $\mathrm{Mn}$ and $\mathrm{Cu}$, Saba pulp is twice as low in $\mathrm{K}$ as banana. According to Diabagaté et al (2019), Saba senegalensis has a concentration of $116.96 \mathrm{mg} / 100 \mathrm{~g}$. This concentration is similar to those obtained in this study. 


\section{Conclusion}

At the end of this study, it should be noted that Saba senegalensis pulp has a nutritional potential that differentiates it from banana, papaya and pineapple. This fruit has a strong antioxidant activity and is very rich in polyphenols, flavonoids, $\beta$-carotene (vitamin A), $\mathrm{Ca}$ and $\mathrm{Fe}$. This study is of particular interest to both consumers and industry. It will also be used to enhance the value of $S a b a$ Senegalensis fruit in Côte d'Ivoire.

\section{COMPETING INTERESTS}

The authors declare that they have no competing interests.

\section{AUTHORS' CONTRIBUTIONS}

This work was carried out in collaboration with all authors. Author YEK collected the samples, carried out the laboratory work, performed the statistical analysis and wrote the first draft of the manuscript. AC and OKK Contributed to the drafting of the protocol and the manuscript. AC, OKK, EHG: participated in the correction of the manuscript. NGA supervised, authorised the study analyses and participated in the correction of the manuscript. All authors read and approved the final manuscript.

\section{REFERENCES}

Abbaspour N, Hurrell R, Kelishadi R. 2014. Revue sur le fer et son importance pour la santé humaine. J Res Med Sci., 19(2): 164-74.

AFNOR (Agence Française de Normalisation). 1991. Recueil des normes françaises d'agroalimentaire. AFNOR, Paris (France), $159 \mathrm{p}$.

Aké M, Poby AG, Malan KA, Tebi A and Monnet D. 2001. Effet de la suplementation en vitamine A sur les marqueurs de la nutrition dans la prise en charge de la malnutrition de l'enfant. Annual Biological Clinical., 59: 417-421.

Angaman D. 2001. Les plantes alimentaires vendues sur les marchés d'Abidjan. Thèse de doctorat, Université de Cocody, Abidjan, Côte d'Ivoire, 189 p.
AOAC (Association of Official Analytical Chemist). 1990. Official Methods of Analysis $\left(15^{\text {th }} \mathrm{Edn}\right)$. AOAC: Washington DC. http://www.aoac.org/vmeth/page1.ht Arbonnier M. 2002. Arbres, Arbustes et Lianes des Zones Sèches d'Afrique de l'Ouest. (2nd édition). CIRAD-France ; $573 \mathrm{p}$.

Bakhoum C, Ndour B, Akpo LE. 2012. Natural regeneration of woody stands in the groundnut Basin lands in the sudanosahelian zone (Region of Kafrrine, Senegal). Journal of Applied Environmental and Biological Sciences, 2(7): 271-280.

Ballo M, Somboro AM., Maiga M, Diarra B, Sanogo M, Denou A, TOGOLA A, YOUL, Sekou BAH EH, Sanogo R, Diallo D. 2020. Evaluation of antimycobacterial activity of medicinal plants used by Malian traditional medicine practitioners to treat tuberculosis. Int. J. Biol. Chem. Sci., 14(9): $\quad 3145-3155$. DOI: 10.4314/ijbcs.v14i9.14

Boamponsem GA., Johnson FS, Mahunu GK, Awiniboya SF. 2013. Détermination of Biochemical Composition of Saba senegalensis. Asian Journal of Plant Science and Research, 3(1): 31-36.

Diabagaté F, Traoré S, Cissé M, Soro D, Brou K. 2019. Biochemical characterization and nutritional profile of the pulp of Saba Senegalensis from Côte d'Ivoire forest. American Journal of Food and Nutrition, 7(1): 19-25. DOI: 10.12691/ajfn-7-1-4

Dubois M, Gilles KA, Hamilton JK, Robert PA, Smith F. 1956. Colorimetry method for determination of sugar and related substances. Analytical Chemistry, 28: 350-356.

DOI : https://doi.org/10.1021/ac60111a017

Edmée M, Sidia DB. 2019. Circulation des produits forestiers non-ligneux à Dakar : Logiques et fonctionnement des filières de Detarium senegalense et Saba senegalensis. Géocarrefour. DOI: 10.4000/geocarrefour.13518

Kini F, Saba A, Ouédraogo S, Tingueri B, Sanou G, Guissou IP. 2008. Nutritional and Therapeutic Potential of Some Wild 
Fruit Species of Burkina Faso. African Pharmacopoeia and Traditional Medicine, 15: 32-35.

Kini F, Saba A, Parkouda C, Ouedraogo S, Guissou, P. 2012. Partial Phytochemical Characterization of the Fruits of Saba senegalensis (Apocynacaea) and Landolphia heudolotii (Apocynaceae). Pharmacopée et Médecine Traditionnelle Africaines, 16 : 32-35.

Koné M, Atindehou K, Tere H, Traore D. 2002. Quelques plantes médicinales utilisées en pédiatrie traditionnelle dans la région de Ferkessedougou (côte-d'ivoire). Actes du colloque international, Centre Suisse du 27-29 Août 2001. Rev. Inter. Sci. de la Vie et de la Terre, $\mathrm{N}^{\circ}$ spécial.

Koné WM, Kamanzi K, Terreaux C. 2004. Traditional medicine in North Côted'Ivoire: screening of 50 medicinal plants for antibacterial activity. Journal of Ethnopharmacology, 93(1): 43-49. DOI: 10.1016/j.jep.2004.03.006

Kouyaté, Aboubacar D, Ismaila D, Elie AP, Siaka DT, Anne ML, Patrick VD. 2021. Local knowledge of Saba Senegalensis fruits against malnutrition in Mali. Forests, trees and livelihoods, 30(1): 4756.

DOI:

10.1080/14728028.2020.1857310

Marinova D, Ribarova F, Atanassova M. 2005. Total phenolics and total flavonoids in bulgarian fruits and vegetables. Journal of the University of Chemical Technology and Metallurgy, 40(3): 255-260.

Muanda FN. 2010. Identification de polyphénols, évaluation de leur activité antioxydante et étude de leurs propriétés biologiques. Thèse de doctorat de l'Université Paul Verlaine-Metz, 295 p.

Norme CEE-ONU. 2013. Relative à la commercialisation et le contrôle de la qualité commerciale de l'ananas.

OMS et FAO. 2014. Fruits et légumes pour la santé Rapport de l'atelier conjoint FAO/OMS, 1er au 3 septembre 2004 Kobe (Japon).
Piste P, Didwagh S, Mokashi A. 2013. Calcium and its Role in Human Body. International Journal of Research in Pharmaceutical and Biomedical Sciences, 4(2): 659-668.

Sarr M, Ndiaye ND, Ayessou NC, Faye PG, Cisse M, Sakho M, Diop, CM. 2018. Saba senegalensis: Key Features and Uses. Food and Nutrition Sciences, 9: 1099. 1111.

DOI: https://doi.org/10.4236/fns.2018.99080

Sarr S, Fall A, Gueye R, Diop A, Sene B, Diatta K, NDiaye B, Diop YM. 2015. Evaluation de l'activité antioxydante des extraits des feuilles d'Aphania senegalensis (Sapindaceae) et de Saba senegalensis (Apocynaceae). International Journal of Biological and Chemical Sciences, 9(6): 2676-2684.

DOI: http://dx.doi.org/10.4314/ijbcs.v9i6.13

Tiendrebeogo S, Ganou L, Compaoré C, Tapsoba F, Dicko MH. 2020. Biochemical composition of Saba senegalensis fruits from Burkina Faso. African Journal of Food Science, 14(10): 322-329. DOI: 10.5897/AJFS2020.1992

Yougbaré-Ziébrou M, Ouédraogo N, Lompo M, Bationo H, Yaro B, Gnoula C, Sawadogo W, Guissou I. 2015. Activités anti-inflammatoire, analgésique et antioxydante de l'extrait aqueux des tiges feuillées de Saba senegalensis Pichon (Apocynaceae). Lavoisier SAS. DOI : 10.1007/s10298-015-0992-

Gning O, Sarr O, Gueye M, Akpo L, Ndiaye P. 2013. Valeur socio-économique de l'arbre en milieu malinké (Khossanto, Sénégal). Journal of Applied Biosciences, 70(1): $\quad 5617 . \quad$ DOI: 10.4314/jab.v70i1.98765

Gning ON, Sarr O, Akpo LI. 2014. Richesse de la pharmacopée malinké: rôle medicinal de l'arbre a Khossanto : (Kédougou, Sénégal oriental). Journal of Applied Biosciences. 74: 6043- 605. DOI: http://dx.doi.org/10.4314/jab.v74i1.11 